«Системні технологіï» 2 (133) 2021 «System technologies»

DOI 10.34185/1562-9945-2-133-2021-09

UDC 519.25:681.5

O.P. Sarychev, B.A. Perviy

\title{
REVEALING CHANGES IN THE SPACE OBJECTS MOTION DESCRIBED BY AUTOREGRESSIVE MODELS
}

The task of revealing changes in the non-functioning Sich-2 spacecraft motion is completed using autoregressive models and time series of TLE elements. The developed method is recomended to use for revealing changes in the movement of space objects during their long-term operation. Keywords: TLE elements, structural uncertainty, beta distribution, unequally spaced observations.

Introduction. Timely detection of changes in the characteristics of space objects during their long-term operation is one of the main tasks in the development and study of on-board systems to support the efficiency of their functioning. To detect changes in the characteristics of the functioning of dynamic systems based on the results of their observation, a method of statistical classification based on modeling in the class of autoregressive equations [1] - [2] has been developed.

The purpose of this work is to apply the developed method of statistical classification to detect changes in the non-functioning Sich-2 spacecraft motion. Since the modeling problems in the class of autoregressive models are posed under conditions of structural uncertainty (the structures of autoregressive models are not known a priori), the results of [3] - [4] obtained within the framework of the method of group consideration of arguments are used to solve them.

An example of successful detection of changes in the properties of dynamic systems based on regression equations is the work [5], where an approach to the construction of mathematical models for monitoring the technical state of power plants under conditions of long-term operation is proposed and substantiated.

\section{Major part.}

1 The task of detecting changes in "Sich-2" spacecraft motion

Methods of statistical classification, developed in [1] - [2], are applied to detect changes in the motion of the Ukrainian spacecraft "Sich-2" based on the modeling of time series of TLE-elements (two-line elements) [6]. The Sich-2 spacecraft is a smallsized spacecraft for remote sensing of the Earth, designed to observe the Earth's sur-

(C) Sarychev O.P., Perviy B.A., 2021 


\section{«Системні технології» 2 (133) 2021 «System technologies»}

face in the optical and mid-infrared ranges. It functioned in 2011-2012, in December 2012 communication with the spacecraft was lost.

Determination of the order and estimation of the coefficients of autoregressive models in conditions of structural uncertainty by the number and composition of regressors is an actual problem of the theory of identification, and there are various approaches to its solution. In the overwhelming majority of cases, existing identification methods do not assume that in autoregressive models, certain relationships are satisfied between the coefficients at the previous values of the variables. In our opinion, such ratios are natural: past values close in time should have coefficients close to each other in the model, and past values more distant in time should have less close ones. When choosing one or another relationship between the autoregression coefficients, it is necessary to take into account the "physics" of the object, the available information, as well as the discreteness of observations in time. Examples of this approach are moving average, exponential smoothing, and other methods with predefined smoothing windows.

In this paper, we propose to search for the optimal smoothing window in the family of probability density functions of beta distributions using the principles of the method of argument group consideration (MAGC) [3] - [4].

Let the functioning of a dynamic object obey the autoregressive model of the following form

$$
\left.\stackrel{*}{x_{i}}=\stackrel{\circ}{\mu_{0}}+\stackrel{\circ}{\mu} \underset{x}{ } \cdot \stackrel{\circ}{\left(\theta_{1}\right.}, \stackrel{\circ}{\theta_{2}}, \ldots, \stackrel{\circ}{\theta} p\right)^{\mathrm{T}}\left(\stackrel{*}{x_{i-1}}, \stackrel{*}{x_{i-2}}, \ldots, \stackrel{*}{x_{i-p}}\right)+\zeta_{i-1}
$$

where $x_{i}$ is the unobservable value of the output variable of the object at a discrete time $t=t_{i}, i=1,2, \ldots, n ; n$ - the total number of observations; $p$ - the number of previous values of the output variable that are involved in the formation of its current value with weighting coefficients $\stackrel{\circ}{\theta_{1}}, \stackrel{\circ}{\theta_{2}}, \ldots, \stackrel{\circ}{\theta_{p}}$ (we will call $p$ the depth or the order of autoregression); $\stackrel{0}{\mu_{0}}, \stackrel{o}{\mu_{x}}$ - unknown scalar deterministic coefficients; $\zeta_{i-1}$ is an unobservable random scalar variable.

Let the weight coefficients $\stackrel{\circ}{\theta_{1}}, \stackrel{\circ}{\theta}_{2}, \ldots, \stackrel{\circ}{\theta}_{p}$ in (1) be determined by the rule

$$
\stackrel{\circ}{\theta}_{j}=F(j \cdot \Delta)-F((j-1) \cdot \Delta), F(v)=\int_{-\infty}^{v} f(u) d u, j=1,2, \ldots, p, \Delta=1 / p,
$$


«Системні технології» 2 (133) 2021 «System technologies»

where $F(v)$ is the probability function of the beta distribution; $\Delta$ - sampling step in $u$ segment $[0,1] ; f(u)$ - the probability density function of the beta distribution [7] - [8]:

$$
f(u)=\left\{\begin{array}{c}
\frac{\Gamma(\alpha+\beta)}{\Gamma(\alpha) \Gamma(\beta)} \cdot u^{\alpha-1}(1-u)^{\beta-1}, u \in[0,1] ; \\
0, u \notin[0,1] .
\end{array}\right.
$$

where $\Gamma(\cdot)$ is the gamma function $[8] ; \alpha, \beta=1,2, \ldots, l_{\max }$ - positive integer values; $l_{\text {max }}$ is the a priori given value.

The assignment of weights $\stackrel{0}{\theta_{1}}, \stackrel{\circ}{\theta}_{2}, \ldots, \stackrel{o}{\theta}_{p}$ based on these functions makes it possible to carry out modeling in a wide class of autoregressive models. So, for the values of the parameters $p=\alpha=\beta=1$ we are dealing with the usual first-order autoregression; the case $p>1, \alpha=\beta=1$ is the $p$ order moving average autoregression; case $p>2, \alpha=\beta=1,2, \ldots$ - the $p$ order autoregression with symmetric weight functions (including those close to the density functions of the "truncated" normal distribution); case $p>1, \alpha=1, \beta=2,3, \ldots$ - the $p$ order autoregression with asymmetric weight functions, including those close to the density functions of the "truncated" exponential (exponential) distribution; case $p>1, \alpha, \beta=1,2, \ldots, \alpha<\beta$ - the $p$ order autoregression with asymmetric weight functions, including those close to the density functions of the "truncated" logarithmic normal distribution.

Let for observations of the output variable of the object be fulfilled

$$
x_{i}=\stackrel{*}{x}_{i}+\varepsilon_{i}, \quad i=1,2, \ldots, n
$$

where $x_{i}$ is the observed value of the variable at the moment of time $t=t_{i}$, * $x_{i}$ is the unobservable value; $\varepsilon_{i}$ - random unobservable measurement error.

Based on the results of observations (4), it is necessary to determine the optimal values of the parameters $\alpha, \beta$ in (2) - (3) and estimate the coefficients in $\stackrel{\circ}{\theta_{1}}, \stackrel{\circ}{\theta_{2}}, \ldots, \stackrel{\circ}{\theta_{p}}(1)$.

The Sich-2 spacecraft motion models were developed using the time series of its TLE elements (Two Line Element set) [9] on the basis of an iterative procedure for estimating the coefficients of beta autoregressive models under conditions of unequally spaced observations, developed in [10] - [11]. The TLE time series elements are represented by the variables indicated in Table. 1 . For modeling, samples of time series were used, the initial observation on August 17, 2011 at 09:00. 57 minutes 37 
«Системні технологіï» 2 (133) 2021 «System technologies»

sec. (observation No. 1) and the finite observation on July 8, 2019 at 15:00. 46 minutes 42 sec. (observation No. 6064).

Table 1

List of variables for Sich- 2 TLE data

\begin{tabular}{|c|l|l|}
\hline Designation & \multicolumn{1}{|c|}{ Title } & \multicolumn{1}{c|}{$\begin{array}{c}\text { Unit of } \\
\text { measurement }\end{array}$} \\
\hline$x_{1}$ & Apogee & $\mathrm{km}$ \\
\hline$x_{2}$ & Perigee & $\mathrm{km}$ \\
\hline$x_{3}$ & Eccentricity & - \\
\hline$x_{4}$ & Inclination & $\mathrm{deg}$ \\
\hline$x_{5}$ & Right ascension of the ascending node & $\mathrm{deg}$ \\
\hline$x_{6}$ & Argument of perigee & $\mathrm{deg}$ \\
\hline$x_{7}$ & Mean anomaly & $\mathrm{deg}$ \\
\hline$x_{8}$ & Revolution number at epoch & revs \\
\hline$x_{9}, t_{n a k}$ & Accumulated time & $\mathrm{hrs}$ \\
\hline$x_{10}, \tau_{i}$ & $\begin{array}{l}\text { The time interval between the current and } \\
\text { the previous observation }\end{array}$ & $\mathrm{hrs}$ \\
\hline
\end{tabular}

Simulations were carried out for six main variables, since the variable $x_{4}$ (inclination) is constant. Additional variables $x_{8}, x_{9}$ were used to construct figures, and the variable $x_{10}$ was used to calculate the power to which the components of the coefficients are raised in the iterative procedure for parametric identification of autoregressive models in conditions of unequally spaced observations [10] - [11].

In accordance with [10] - [11], the structure of the beta-autoregressive model is determined by a special weight function that specifies the relationship between the coefficients of the autoregressive model. The best structure corresponds to the smallest residual root mean square error among all enumerated model structures. By dividing the entire observation period into intervals corresponding to the cycles of variation of the variables $x_{5}, x_{6}, x_{7}$ and, it is possible to reveal the change in the structure, coefficients, and mean-square error of the best model during the transition from interval to interval for each of the variables.

2 Results of change detection modeling of the Sich-2 spacecraft

In [10], the behavior of the structure, coefficients and errors of optimal models for 9 cycles in a variable $x_{5}$ and for 25 cycles in variables $x_{1}, x_{2}, x_{3} x_{6} x_{7}$ are investigated. In this work, an attempt has been made to detect in more detail changes in the Sich-2 spacecraft motion. 


\section{«Системні технологіï» 2 (133) 2021 «System technologies»}

For this purpose, each of the 9 cycles of the variable and each of the 25 cycles in the variables $x_{6}$ and ${ }^{x_{7}}$ (additionally $x_{1}, x_{2}, x_{3}$ ) are additionally divided into several intervals so that the average volume of the new intervals was about 50 values. The quantity of new intervals for the variable $x_{5}$ was 119 , and for the rest of the variables - 123. The total number of models built for the five variables was $n_{m}=119+4 \cdot 123=611$

The structure of the constructed models has the form

$$
\hat{x}_{i}=a_{1} x_{i-1}+a_{2} x_{i-2}+\ldots+a_{p} x_{i-p}
$$

where $a_{j}, j=1,2, \ldots, p$ are the autoregression coefficients that need to be estimated from the sample of observations; $p$ - autoregression order.

Figures 1 - 4 represent the graphs of changes in the mean square errors (RMS) of autoregressive models for six variables over new intervals. The root-mean-square errors of the constructed models for steady-state modes are: for apogee and perigee $\sim 1$ meter, for eccentricity $\sim 0.510-5$, for longitude of the ascending node $\sim 0.05$ degrees, for argument of perigee $\sim 0.5$ degrees, for mean anomaly $\sim 0.5$ degrees. In the graphs of the mean square errors of autoregression models, there are sharply distinguished values:

by variable ${ }^{x_{1}}$ - for intervals $3,15,18,41,54-67$;

by variable $x_{2}$ - for intervals $3,15,18,41,54-67$;

by variable $x_{3}$ - for intervals 40 - 64, 93;

by variable $x_{5}$ - for intervals $61,68,81,112$;

by variable $x_{6}$ - for intervals $59-67$;

by variable $x_{7}$ - for intervals $55,60-63,82,123$.

From a comparison of the results obtained, it follows that the most significant deviation from the main mode of motion of the Sich-2 spacecraft was observed at intervals with numbers from 54 to 67 (out of 123), which corresponds to the time period from September 2013 to May 2015.

In the practice of modeling time series, there is a technique that is called "modeling on a sliding interval". Its essence lies in the fact that the simulation interval of a given size "slides" along the time axis of observations, that is, it moves to the right when a new observation is added. This technique is used to assess the predictive 
«Системні технології» 2 (133) 2021 «System technologies»

ability of the models (observations that follow the training interval are taken as validations) and to detect changes in the motion mode of the Sich-2 spacecraft.

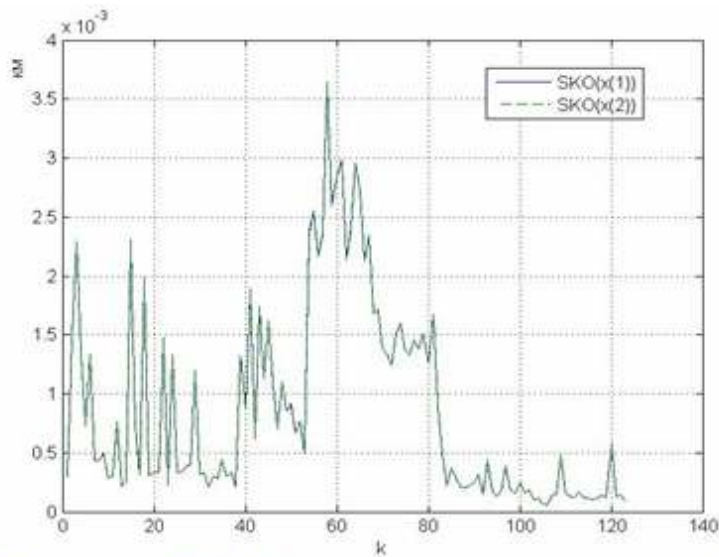

Figure 1-RMS of autoregression models for $x_{1}$-apogee \& $x_{2}$ - perigee

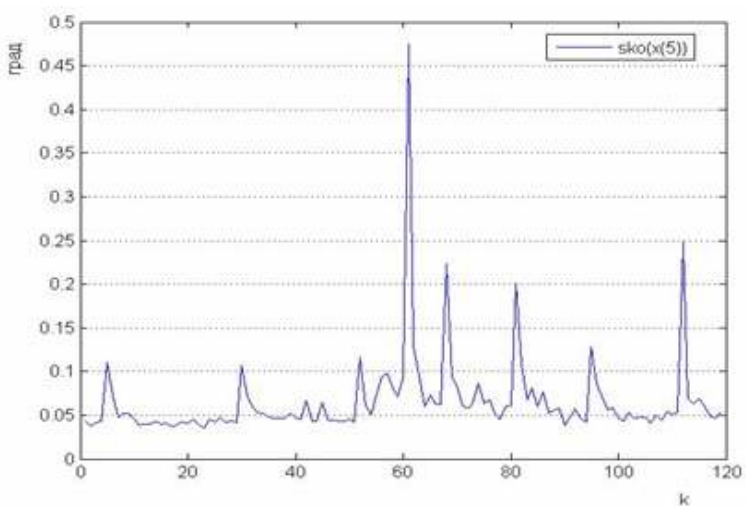

Figure 3 - RMS of autoregression models for $x_{5}$-right ascension of the ascending node

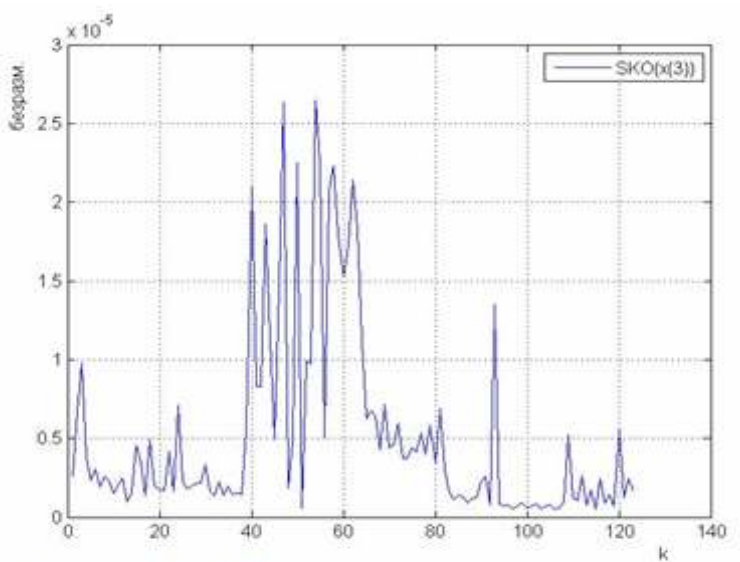

Figure 2 - RMS of autoregression models for $x_{3}$-eccentricity

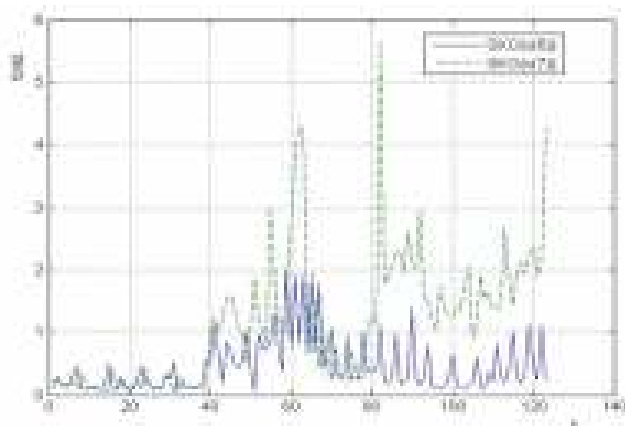

Figure 4 - RMS of autoregression models for $x_{6}$-argument of perigee II $x_{7}$ - mean anomaly

3 Step-by-step forecasting of variables on a sliding interval in order to detect changes in motion modes

Modeling on a sliding interval was carried out on a time series section (observations №2651 to 2803), which contains intervals №54 to 56 (out of 119) for a variable $x_{5}$, and intervals №57 to 59 (out of 123 ) for a variable $\underline{x_{6}}$, introduced in paragraph 2. The sample size of the sliding window was 40 observations, the number of sliding window positions was 113 .

The errors of step-by-step forecasting using autoregressive models built on training sliding intervals were used as indicators of movement changes.

Figures 5 - 9 show the graphs of changes in the model error on the training sliding interval for six main variables. 


\section{«Системні технологіï» 2 (133) 2021 «System technologies»}

For variables $x_{1}$ and $x_{2}$ in the section with numbers of sliding intervals numbered 47, 48, ..., 83 (which correspond to the ranges of observation № 2697 - 2736, $2698-2737, \ldots, 2633$ - 2772), increased values of the mean square error of the models are obtained.

For the variable $x_{3}$ in the section with the numbers of sliding intervals № 73 , $74, \ldots, 101$ (which correspond to the ranges of observation № 2723 - 2762, 2724 $2763, \ldots, 2751-2790)$, there is a decrease in the mean square error of the models followed by its increasing

For the variable $x_{5}$ in the section with № of sliding intervals $48,49, \ldots, 85$ (which correspond to the ranges of observation № 2698 - 2737, $2699-2738, \ldots, 2735$ - 2774), there is a tendency towards an increase in the mean square error of the models. For the variable $x_{6}$ in the section with the numbers of sliding intervals 52, 53, ..., 97 (which correspond to the ranges of observation № 2702 - 2741, 2703 $2742, \ldots, 2747-2786$ ), there is a tendency towards an increase in the mean square error of the models. A sharp upward peak is obtained for the variable ${ }^{x_{7}}$ on a sliding interval, which corresponds to the range of observation № 2738 - 2776. A detailed visual analysis of the time series of the six main TLE elements (inclination was constant, 98 degrees) shows:

1) noticeable peaks in the behavior of variables $x_{1}, x_{2}, x_{5} x_{6}$ and have occurred starting from observation № 2744 (December 13, 2013);

2 ) the change in the variable, starting from observation №2745, clearly changes its behaviour;

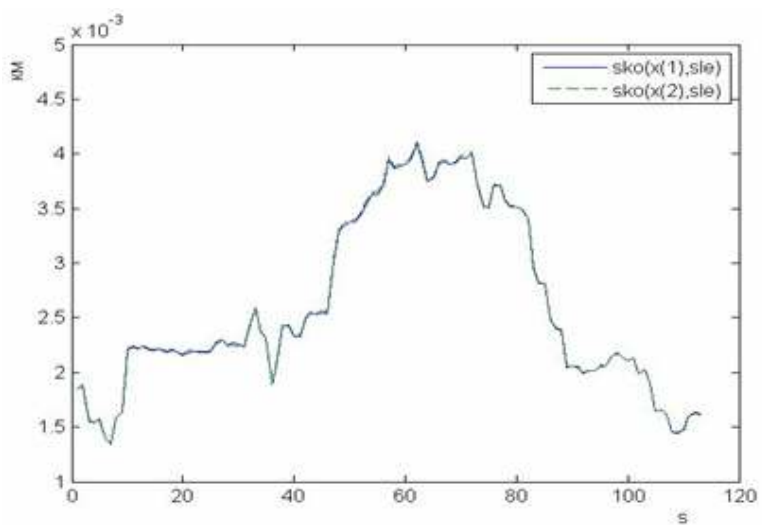

Figure 5 - RMS in sliding interval for $x_{1}$ - apogee \& $x_{2}$-perigee

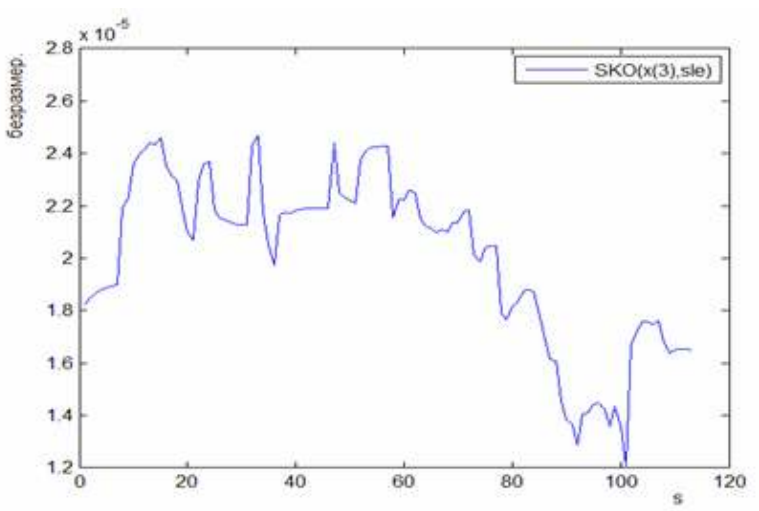

Figure 6 - RMS in sliding interval for $x_{3}$ - eccentricity 
«Системні технологіï» 2 (133) 2021 «System technologies»

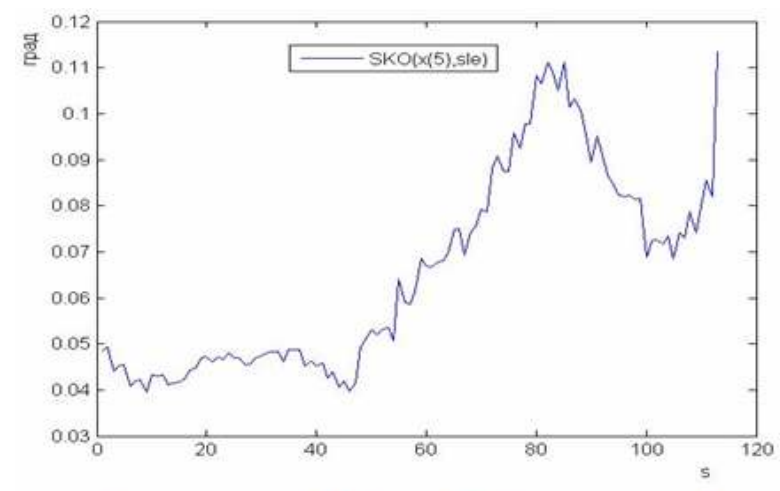

Figure 7 - RMS in sliding interval for $x_{5}$ - right ascension of the ascending node

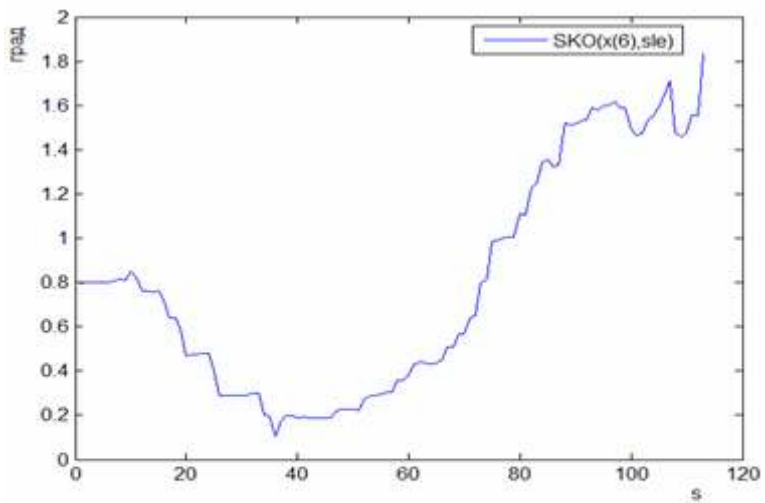

Figure 8 - RMS in sliding interval for $x_{6}$ - argument of perigee

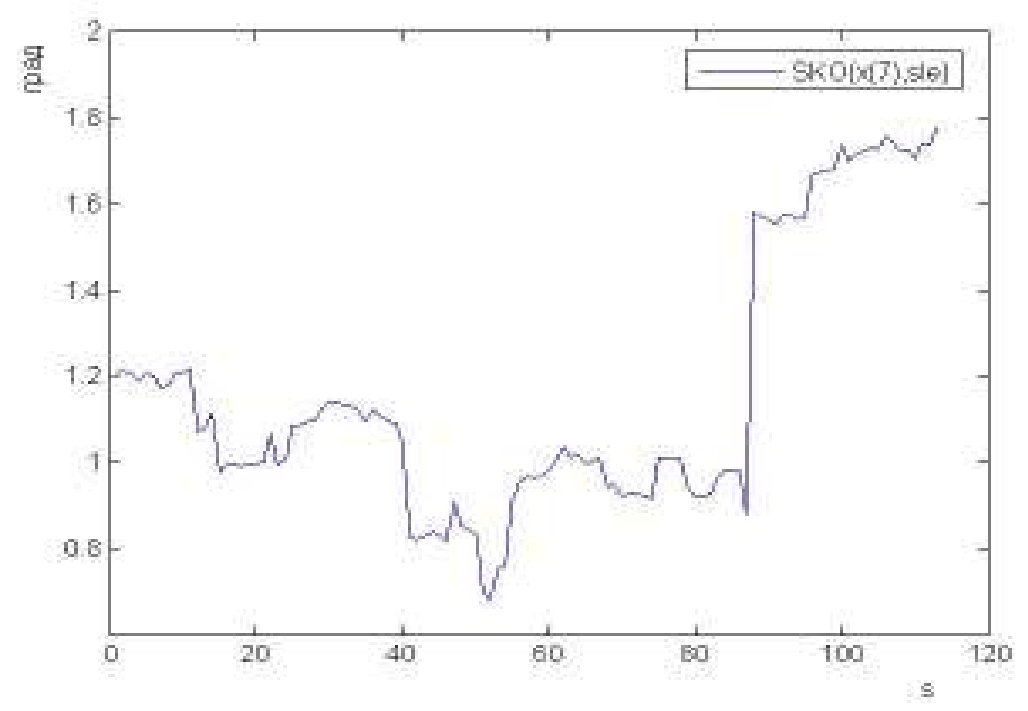

Figure 9 - RMS in sliding interval for $x_{7}$ - mean anomaly

3) a noticeable peak in the behavior of the variable occurred at the time of observation №2777.

Comparison of Fig. 5 - 9 with the results of visual analysis of the initial time series shows that the root-mean-square errors on the sliding interval of the models for the variables $x_{1}, x_{2}, x_{3}, x_{5} x_{6}$, reflect a noticeable change in the behavior of the Sich-2 spacecraft that occurred on December 13, 2013.

The drastic change in the behavior of the variable that occurred in observation № 2777 is consistent with a change in the rms error of the model for this variable on the sliding interval 2738 - 2776, but is not coherent with the rms errors of the models of other variables. 
«Системні технології» 2 (133) 2021 «System technologies»

Conclusion. The task of revealing changes in the non-functioning Sich-2 spacecraft motion is completed using autoregressive models and time series of TLE elements.

A drastic change in the behavior of the Sich-2 spacecraft occurred on December 13, 2013. To establish the causes of this event, additional information must be involved.

The developed method is recomended to use for revealing changes in the movement of space objects during their long-term operation.

\section{REFERENCES}

1. Sarychev A. P. Classification of the States of Dynamic System, which Functioning Is Described by Vector Autoregresion / A. P. Sarychev // System technologies. The regional interuniversity collection of scientific works. - Volume 4 (123). - Dnipro, 2019. - P. 131-154.

2. Sarychev A. P. Classification of the States of Dynamic System, which Functioning Is Described by One-dimensional Autoregresion / A. P. Sarychev // System technologies. The regional interuniversity collection of scientific works. - Volume 5 (124). Dnipro, 2019. - P. 61-76.

3. Alexander P. Sarychev Modeling in the Class of Autoregression Equations Systems in Conditions of Structural Uncertainty / A. P. Sarychev // Journal of Automation and Information Sciences. - Begell House Inc. - 2015. - Volume 47, Number 7. - P. 59-88.

4. Aleksandr Sarychev. Modelirovanie slozhnyih sistem v usloviyah strukturnoy neopredelyonnosti: regressionnyie i avtoregressionnyie modeli / A. P. Sarychev LAP LAMBERT Academic Publishing RU, Saarbr?cken, Deutschland. - 2016. - 274 c.

5. Mirgorod V.F. Matematicheskie modeli protsessov upravlyaemogo izmeneniya sostoyaniya silovyih i energeticheskih ustanovok : diss. ... d-ra tehn. nauk / Mirgorod Vladimir Fyodorovich. - Dnepropetrovsk, 2012. - 344 s.

6. FSCC TLE Source - https://www.space-track.org/\#Landing

7. Spravochnik po teorii veroyatnostey i matematicheskoy statistike / V. S. Korolyuk, N. I. Portenko, A. V. Skorohod, A. F. Turbin. - M. : Nauka, 1985. - 640 s.

8. Korn G. Handbook of mathematics for scientists and engineers: trans. with English / G. Korn, T. Korn. - 4th edition. - M.: Nauka, 1977. - 831 c.

9. TLE-elements of «Sich-2»- https://www.n2yo.com/satellite/?s=37794.

10. Sarychev O. P. Optimal regressors search subjected to vector autoregression of unevenly spaced TLE series / O. P. Sarychev, В. А. Perviy, // Системні технології. Випуск 2 (121). - 2019. - С. 95-110. 


\section{«Системні технологіï» 2 (133) 2021 «System technologies»}

11. Sarichev O. P. Autoregression models of space objects movement represented by TLE elements / O. P. Sarichev, В. А. Perviy // Системні технології. - Випуск 2 (127). - 2020. - C. 103-116.

Received 12.02.2021. Accepted 15.02.2021.

\section{Виявлення змін в русі космічних об'єктів на основі авторегресійних моделей}

Розглянуто рішення задачі виявлення зміни руху нефункціонуючого космічного аnaрату «Січ-2» на основі статистичної класифікації станів динамічних систем. Побудову моделей руху космічного апарату «Січ-2» проведено з використанням часових рядів його TLE-елементів (Two Line Element set) з нерівновіддаленими спостереженнями на основі ітераційної процедури оцінювання коефіцієнтів бета-авторегресійних моделей в умовах структурної невизначеності. Виявлено різку зміну руху поведінку космічного апарату «Січ-2», яка виникла 13 грудня 2013 г. Для встановлення причин чієї події необхідно залучення додаткової інформації. Метод доцільно використовувати для виявлення зміни руху об'єктів ракетно-космічної техніки в процесі їх тривалої експлуатації.

\section{Обнаружение изменений в движении космических объектов на основе авторегрессионных моделей}

Решена задача обнаружения изменения движения нефункционирующего космического аппарата «Сич-2» на основе авторегрессионных моделей, построенных по временным рядам TLE-элементов. Разработанный метод целесообразно использовать для обнаружения изменения движения объектов ракетно-космической техники в процессе их длительной эксплуатации.

Саричев Олександр Павлович - доктор технічних наук, провідний науковий співробітник, Інститут технічної механіки НАН України і ДКА України.

Первій Богдан Андрійович - молодший науковий співробітник, Інститут технічної механіки НАН України і ДКА України.

Сарычев Александр Павлович - доктор технических наук, ведущий на-учно сотрудник, Институт технической механики НАН Украины и ГКА Украины.

Первый Богдан Андреевич - младший научный сотрудник, Ин-ститут технической механики НАН Украины и ГКА Украины.

Sarychev Oleksandr Pavlovich - Doctor of Technical Science, Principal Researcher, Institute of Technical Mechanics of the National Academy of Sciences of Ukraine and State Space Agency of Ukraine.

Perviy Bogdan Andriyovich - Junior Researcher, Institute of Technical Mechanics of the National Academy of Sciences of Ukraine and State Space Agency of Ukraine of Ukraine. 